\title{
Impact of marital status on renal cancer patient survival
}

\author{
Hongzhi Wang ${ }^{1, *}$, Lu Wang ${ }^{1, *}$, Ildar Kabirov ${ }^{1, *}$, Li Peng ${ }^{1}$, Guang Chen ${ }^{1}$, Yinhui Yang ${ }^{1}$, \\ Zamyatnin Andrey $\mathrm{A}^{2,3}$ and Wanhai $\mathrm{Xu}^{1}$ \\ ${ }^{1}$ Department of Urology, The 4th Affiliated Hospital of Harbin Medical University, Harbin, 150001, China \\ ${ }^{2}$ Institute of Molecular Medicine, Sechenov First Moscow State Medical University, Moscow 119991, Russia \\ ${ }^{3}$ Belozersky Institute of Physico-Chemical Biology, Lomonosov Moscow State University, Moscow 119992, Russia \\ *These authors have contributed equally to this work \\ Correspondence to: Wanhai Xu, email: xuwanhai@hrbmu.edu.cn \\ Keywords: renal cancer, marital status, Surveillance, Epidemiology, and End Results, survival analysis, patient demographics \\ Received: March 17, $2017 \quad$ Accepted: June 12, $2017 \quad$ Published: July 26, 2017 \\ Copyright: Wang et al. This is an open-access article distributed under the terms of the Creative Commons Attribution License \\ 3.0 (CC BY 3.0), which permits unrestricted use, distribution, and reproduction in any medium, provided the original author and \\ source are credited.
}

\section{ABSTRACT}

\begin{abstract}
Marital status is an independent prognostic factor for various cancer types. The present study used the Surveillance, Epidemiology, and End Results (SEER) database of the National Cancer Institute (NCI) to analyze the impact of marital status on renal cancer patient survival outcomes. We identified a total of 62,405 eligible patients (23,800 women and 38,605 men). Overall 5-year renal cancer cause-specific survival (CSS) was $80.3 \%$ in the married group, $69.2 \%$ in the widowed group, $78.9 \%$ in the single group, and $76.5 \%$ in the divorced/separated group. The widowed patient group had the highest female/male ratio, more distant metastases, and fewer high-grade (III/IV) tumors. Most widowed patients $(90.4 \%$ ) were elderly ( $>60$ years old). In our study, male renal cancer patients benefited more from marriage than females. We also found that white married patients had better survival outcomes than other white patient groups, but black unmarried and married patients exhibited similar survival outcomes. Our results show that, in general, unmarried patients have higher rates of cancer-specific mortality and highlight the importance of psychological intervention for cancer patients during treatment.
\end{abstract}

\section{INTRODUCTION}

Renal cancer causes 140,000 deaths per year, and is the seventh most common cancer in the world [1]. In 2013, more than 350,000 people were diagnosed with renal cancer [1]. While most renal cancers are localized, low-grade tumors, nearly $17 \%$ of patients had distant metastases at the time of diagnosis [2]. Several factors, such as smoking tobacco [3], hypertension [4], obesity [5, 6], and red meat consumption [7], are associated with renal cancer progression. However, little is known about the roles of socioeconomic status and psychological supports, such as marital status, in renal cancer prognosis. Marital status is an independent parameter to predict survival outcome in various cancers [8-10], and married patients exhibit better survival outcomes than unmarried patients. Married status may be associated with improved social support, higher income, and healthier behaviors, which might improve cancer patient rehabilitation results [1114]. To our knowledge, the effects of marital status on renal cancer patient survival have not yet been studied. Here, we collected data from the Surveillance, Epidemiology, and End Results (SEER) cancer-registry program, including individuals diagnosed with renal carcinoma between 2004 and 2013, and explored the impact of marital status on renal cancer patient cause-specific survival (CSS).

\section{RESULTS}

\section{Patient characteristics}

This study included 62,405 eligible renal cancer patients. Of these, 39627 (63.50\%) were married, 6,674 $(10.69 \%)$ were widowed, 9,346 (14.98\%) were single, and 6,758 (10.83\%) were divorced/separated (Table 1). The widowed patients group had the highest female/male 
Table 1: Patient baseline demographic and clinical characteristics

\begin{tabular}{|c|c|c|c|c|c|c|}
\hline \multirow{2}{*}{ Characteristic } & Total & Married & Widowed & Single & $\begin{array}{l}\text { Divorced/ } \\
\text { separated }\end{array}$ & \multirow{2}{*}{$P$-value } \\
\hline & $(n=62405)$ & $\begin{array}{c}(\mathrm{n}=39627) \\
\mathrm{N}(\%)\end{array}$ & $\begin{array}{c}(n=6674) \\
N(\%)\end{array}$ & $\begin{array}{c}(n=9346) \\
N(\%)\end{array}$ & $\begin{array}{c}(n=6758) \\
N(\%)\end{array}$ & \\
\hline Sex & & & & & & $<0.001$ \\
\hline Male & 38605 & $27104(68.4)$ & $1824(27.3)$ & $5941(63.6)$ & $3736(55.3)$ & \\
\hline Female & 23800 & $12523(31.6)$ & $4850(72.7)$ & $3405(36.4)$ & $3022(44.7)$ & \\
\hline Age & & & & & & $<0.001$ \\
\hline$\leq 60$ & 29301 & $18890(47.7)$ & $639(9.6)$ & $6169(66.0)$ & $3603(53.3)$ & \\
\hline$>60$ & 33104 & $20737(52.3)$ & $6035(90.4)$ & $3177(34.0)$ & $3155(46.7)$ & \\
\hline Race & & & & & & $<0.001$ \\
\hline White & 52479 & $34163(86.2)$ & $5607(84)$ & $7104(76)$ & $5605(82.9)$ & \\
\hline Black & 5561 & $2489(6.3)$ & $672(10.1)$ & $1569(16.8)$ & $831(12.3)$ & \\
\hline AI & 646 & $323(0.8)$ & $69(1.0)$ & $176(1.9)$ & $78(1.2)$ & \\
\hline API & 3346 & $2399(6.1)$ & $314(4.7)$ & $426(4.6)$ & $207(3.1)$ & \\
\hline Unknown & 373 & $253(0.6)$ & $12(0.2)$ & $71(0.8)$ & $37(0.6)$ & \\
\hline Tumor size (cm) & & & & & & $<0.001$ \\
\hline$\leq 7$ & 44561 & $28486(71.9)$ & $4721(70.7)$ & $6499(69.5)$ & $4855(71.8)$ & \\
\hline$>7$ & 15632 & $9932(25.1)$ & $1549(23.2)$ & $2493(26.7)$ & $1658(24.5)$ & \\
\hline Unknown & 2212 & $1209(3.1)$ & $404(6.1)$ & $354(3.8)$ & $245(3.6)$ & \\
\hline Laterality & & & & & & $<0.001$ \\
\hline Left & 30494 & $19271(48.6)$ & $3298(49.4)$ & $4569(48.9)$ & $3356(49.7)$ & \\
\hline Right & 31265 & $20018(50.5)$ & $3252(48.7)$ & $4671(50)$ & $3324(49.2)$ & \\
\hline Bilateral & 560 & 293(0.7) & $107(1.6)$ & $93(1)$ & $67(1)$ & \\
\hline Unspecified & 86 & $45(0.1)$ & $17(0.3)$ & $13(0.1)$ & $11(0.2)$ & \\
\hline SEER stage & & & & & & $<0.001$ \\
\hline Localized & 42448 & $27238(68.7)$ & $4232(63.4)$ & $6384(68.3)$ & 4594(68) & \\
\hline Regional & 9616 & $6332(16)$ & 994(14.9) & $1322(14.1)$ & $968(14.3)$ & \\
\hline Distant & 9200 & $5512(13.9)$ & $1143(17.1)$ & $1470(15.7)$ & $1075(15.9)$ & \\
\hline Unknown & 1141 & $545(1.4)$ & $305(4.6)$ & $170(1.8)$ & $121(1.8)$ & \\
\hline Grade & & & & & & $<0.001$ \\
\hline I/II & 31104 & $20315(51.3)$ & $2827(42.4)$ & 4579(49) & $3383(50.1)$ & \\
\hline III/IV & 16256 & $10788(27.2)$ & $1303(19.5)$ & $2433(26)$ & $1732(25.6)$ & \\
\hline Unknown & 15045 & $8524(21.5)$ & $2544(38.1)$ & $2334(25)$ & $1643(24.3)$ & \\
\hline
\end{tabular}

ratio, more distant metastases, and fewer high-grade (III/ IV) tumors (all $\mathrm{P}<0.001)$. Most widowed patients $(90.4 \%)$ were elderly ( $>60$ years old) $(\mathrm{P}<0.001)$.

\section{Effect of marital status on renal cancer patient CSS}

Overall 5-year renal cancer CSS was $80.3 \%$ in the married group, $69.2 \%$ in the widowed group, $78.9 \%$ in the single group and $76.5 \%$ in the divorced/separated group. ( $\mathrm{P}<0.001, \log$ rank test; Table 2, Figure 1A). Patient sex, age, race, tumor size, grade, laterality, and SEER stage were also identified as risk factors for cancer CSS.

Multivariate analysis showed that marital status was also a prognostic factor. Widowed (hazard ratio [HR], 1.162; confidential interval [CI], 1.095-1.234) and 
Table 2: Univariate and multivariate survival analyses of the impact of marital status on renal cancer CSS

\begin{tabular}{|c|c|c|c|c|c|}
\hline \multirow{2}{*}{ Variable } & \multirow{2}{*}{ 5-year CSS } & \multicolumn{2}{|c|}{ Univariate analysis } & \multicolumn{2}{|c|}{ Multivariate analysis } \\
\hline & & Log rank $\chi^{2}$ test & $P$-value & HR $(95 \% C I)$ & $P$-value \\
\hline Sex & & 76.381 & $<0.001$ & & $<0.001$ \\
\hline Male & $77.1 \%$ & & & Reference & \\
\hline Female & $80.7 \%$ & & & $0.912(0.876-0.950)$ & \\
\hline Age & & 739.793 & $<0.001$ & & $<0.001$ \\
\hline$\leq 60$ & $83.5 \%$ & & & Reference & \\
\hline$>60$ & $73.9 \%$ & & & $1.233(1.185-1.282)$ & \\
\hline Race & & 58.693 & $<0.001$ & & \\
\hline White & $78.6 \%$ & & & Reference & \\
\hline Black & $76.6 \%$ & & & $1.105(1.038-1.177)$ & 0.002 \\
\hline AI & $75.7 \%$ & & & $0.949(0.800-1.124)$ & 0.543 \\
\hline API & $78.5 \%$ & & & $1.046(0.963-1.136)$ & 0.291 \\
\hline Unknow & $93.4 \%$ & & & $0.245(0.152-0.394)$ & $<0.001$ \\
\hline Tumor size (cm) & & 10876.88 & $<0.001$ & & \\
\hline$\leq 7$ & $88.7 \%$ & & & Reference & \\
\hline$>7$ & $55.9 \%$ & & & $2.477(2.379-2.580)$ & $<0.001$ \\
\hline Unknown & $32.6 \%$ & & & $1.350(1.253-1.456)$ & $<0.001$ \\
\hline Laterality & & 2523.04 & $<0.001$ & & \\
\hline Left & $78.7 \%$ & & & Reference & \\
\hline Right & $79.5 \%$ & & & $0.954(0.919-0.990)$ & 0.013 \\
\hline Bilateral & $17.0 \%$ & & & $0.721(0.646-0.804)$ & $<0.001$ \\
\hline Unspecified & $21.4 \%$ & & & $0.646(0.497-0.840)$ & 0.001 \\
\hline SEER stage & & 41800.0 & $<0.001$ & & \\
\hline Localized & $93.9 \%$ & & & Reference & \\
\hline Regional & $72.3 \%$ & & & $3.297(3.097-3.511)$ & $<0.001$ \\
\hline Distant & $13.9 \%$ & & & $19.840(18.740-21.004)$ & $<0.001$ \\
\hline Unknown & $55.3 \%$ & & & $1.957(1.703-2.249)$ & $<0.001$ \\
\hline Grade & & 9611.870 & $<0.001$ & & \\
\hline $\mathrm{I}$ & $94.1 \%$ & & & Reference & \\
\hline II & $92.1 \%$ & & & $1.259(1.122-1.413)$ & $<0.001$ \\
\hline III & $75.7 \%$ & & & $2.536(2.267-2.838)$ & $<0.001$ \\
\hline IV & $47.1 \%$ & & & $4.359(3.833-4.956)$ & $<0.001$ \\
\hline Unknown & $56.5 \%$ & & & $4.020(3.594-4.498)$ & $<0.001$ \\
\hline Marital status & & 441.757 & $<0.001$ & & \\
\hline Married & $80.3 \%$ & & & Reference & \\
\hline Widowed & $69.2 \%$ & & & $1.162(1.095-1.234)$ & $<0.001$ \\
\hline Single & $78.9 \%$ & & & $1.055(0.998-1.114)$ & $<0.057$ \\
\hline $\begin{array}{l}\text { Divorced/ } \\
\text { Separated }\end{array}$ & $76.5 \%$ & & & $1.171(1.104-1.243)$ & $<0.001$ \\
\hline
\end{tabular}


divorced/separated (hazard ratio [HR], 1.171; confidential interval [CI], 1.104-1.243) patients had poorer outcomes than married patients, even after controlling for other risk factors.

The other covariates were also validated as independent factors in predicting renal cancer patient outcome. Female patients had better CSS than male patients (HR 0.912, 95\% CI 0.876-0.950), while black patients had a higher mortality risk than white patients (HR 1.105, 95\% CI 1.038-1.177). Patients with larger, advanced stage, or high-grade tumors, and elderly patients ( $>60$ years of age) had higher mortality rates (Table 2 ).
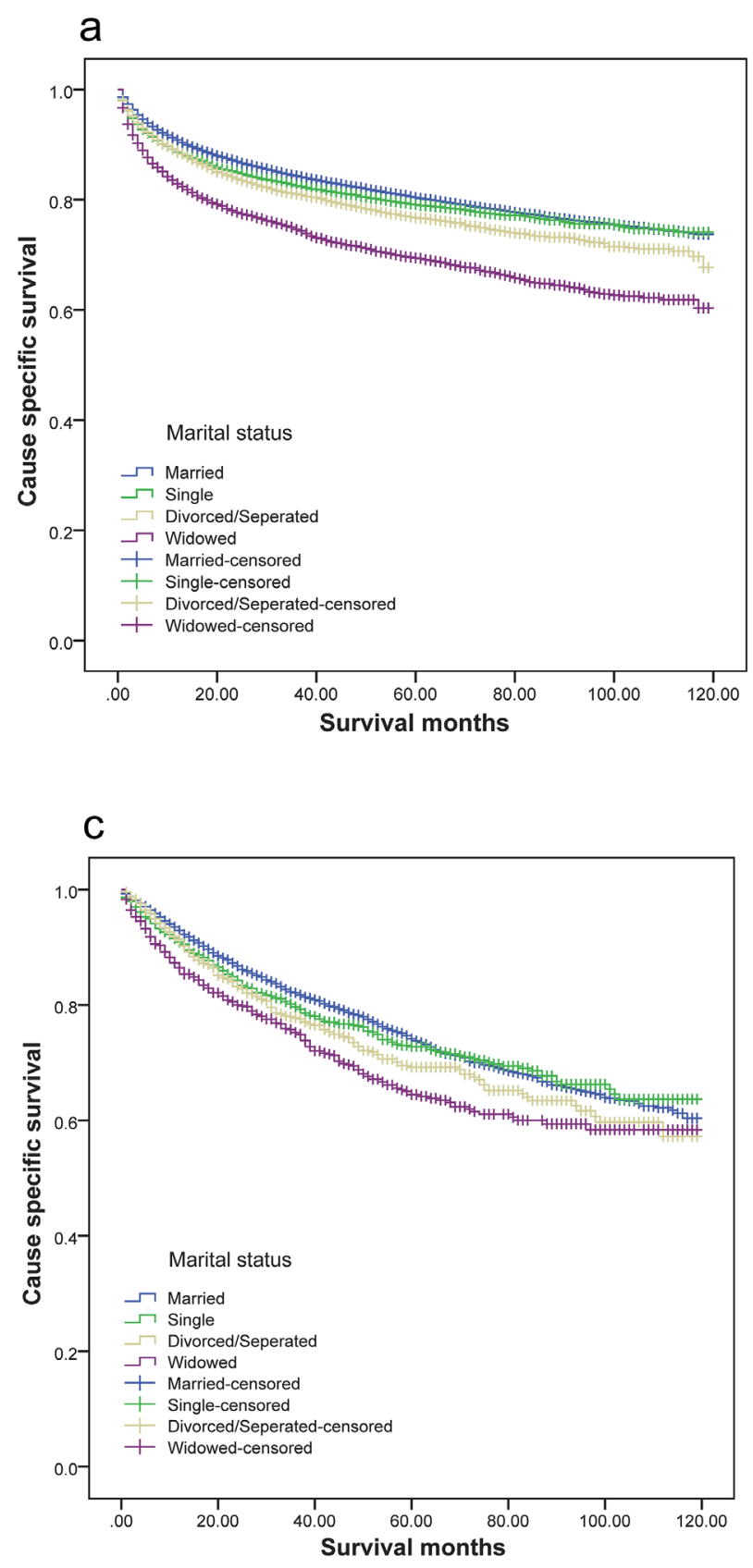

\section{Subgroup analysis of the effects of marital status}

We evaluated the impact of marital status on survival at each stage of renal cancer. Widowed and divorced/separated patients had worse survival rates compared with married patients in each tumor stage (Table 3, Figure 1). However, although single patients had a lower 5-year CSS than married patients with SEER distant stage tumors $(12.5 \%$ vs $15.1 \%, \mathrm{P}<0.001)$, multivariate analysis showed no difference between the two groups in localized $(\mathrm{P}=0.174)$, regional $(\mathrm{P}=0.410)$, and all tumor stages combined $(\mathrm{P}=0.057)$ (Table 3$)$. Widowed
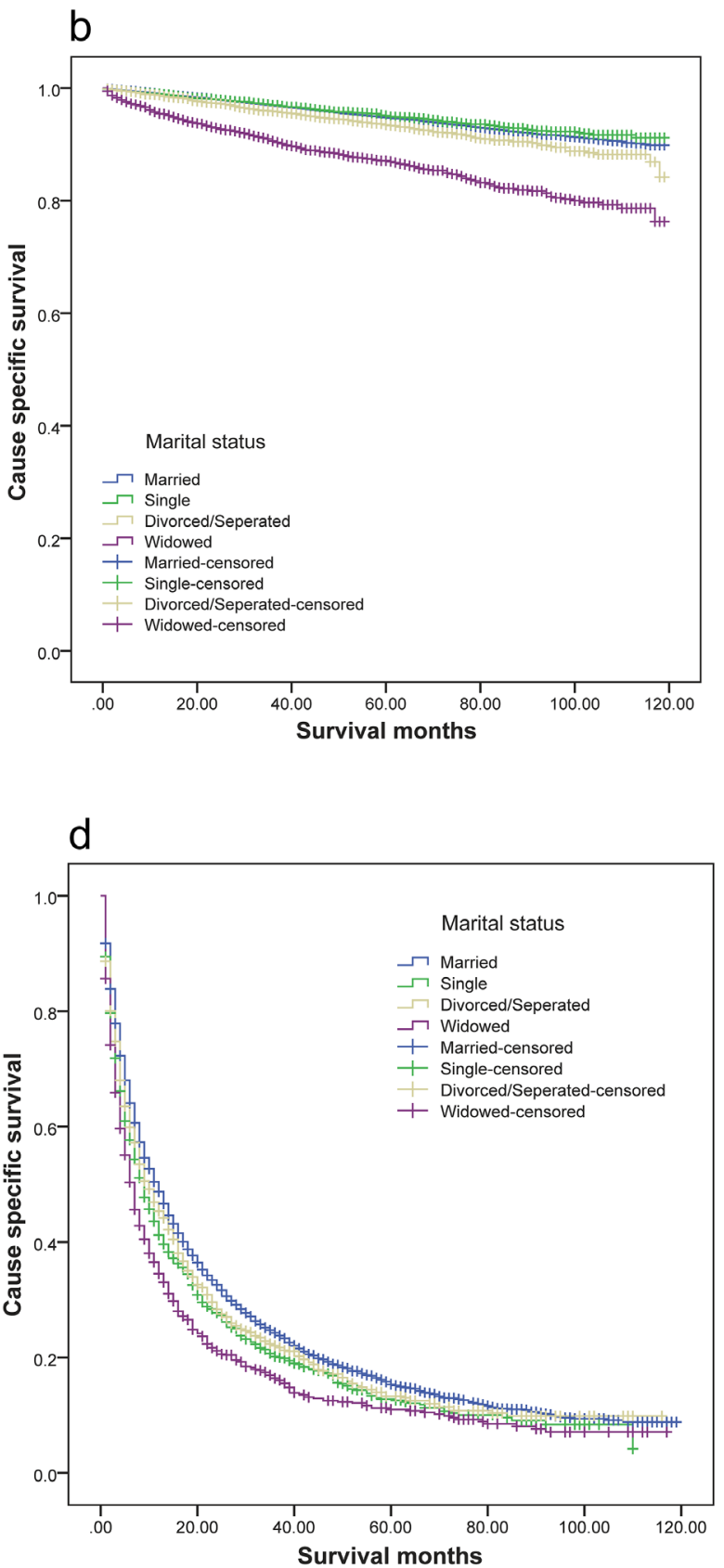

Figure 1: Survival curves of renal cancer patients according to marital status. (a) All stage; $\chi^{2}=441.757, \mathrm{P}<0.001 ;$ (b) localized; $\chi^{2}=407.581, \mathrm{P}<0.001$; (c) regional; $\chi^{2}=33.455, \mathrm{P}<0.001$; (d) distant; $\chi^{2}=80.016, \mathrm{P}<0.001$. 
Table 3: Univariate and multivariate analyses of the impact of marital status on renal cancer CSS based on cancer stage

\begin{tabular}{|c|c|c|c|c|c|}
\hline \multirow{2}{*}{ Variable } & \multirow{2}{*}{ 5-year CSS } & \multicolumn{2}{|c|}{ Univariate analysis } & \multicolumn{2}{|c|}{ Multivariate analysis } \\
\hline & & Log rank $\chi^{2}$ test & $P$-value & HR (95\% CI) & $P$-value \\
\hline \multicolumn{6}{|l|}{ SEER Stage } \\
\hline \multicolumn{6}{|l|}{ Localized } \\
\hline Marital status & & 407.581 & $<0.001$ & & \\
\hline Married & $94.8 \%$ & & & Reference & \\
\hline Widowed & $87.0 \%$ & & & $2.129(1.889-2.400)$ & $<0.001$ \\
\hline Single & $95.1 \%$ & & & $1.100(0.959-1.263)$ & 0.174 \\
\hline Divorced/Separated & $93.4 \%$ & & & $1.399(1.221-1.603)$ & $<0.001$ \\
\hline \multicolumn{6}{|l|}{ Regional } \\
\hline Marital status & & 33.455 & $<0.001$ & & \\
\hline Married & $74.0 \%$ & & & Reference & \\
\hline Widowed & $64.2 \%$ & & & $1.253(1.082-1.450)$ & 0.003 \\
\hline Single & $72.6 \%$ & & & $1.0056(0.928-1.202)$ & 0.410 \\
\hline Divorced/Separated & $69.0 \%$ & & & $1.192(1.036-1.372)$ & 0.014 \\
\hline \multicolumn{6}{|l|}{ Distant } \\
\hline Marital status & & 84.016 & $<0.001$ & & \\
\hline Married & $15.1 \%$ & & & Reference & \\
\hline Widowed & $10.8 \%$ & & & $1.158(1.067-1.257)$ & $<0.001$ \\
\hline Single & $12.5 \%$ & & & $1.131(1.055-1.213)$ & $<0.001$ \\
\hline Divorced/Separated & $13.1 \%$ & & & $1.081(1.002-1.167)$ & 0.045 \\
\hline
\end{tabular}

patients had the lowest 5-year CSS. Compared to married patients, widowed patient 5-year CSS was $7.8 \%$ lower in localized stage $(87.0 \%$ vs $94.8 \%, \mathrm{P}<0.001), 9.8 \%$ lower in regional stage $(64.2 \%$ vs $74.0 \%, \mathrm{P}<0.001)$ and $4.3 \%$ lower in distant stage tumors $(10.8 \%$ vs $15.1 \%, \mathrm{P}<0.001)$. Compared with the married group, divorced/separated patient 5-year CSS was 1.4\% lower in localized stage (93.4\% vs 94.8\%, $\mathrm{P}<0.001), 5 \%$ lower in regional stage $(69 \%$ vs $74 \%, \mathrm{P}<0.001)$ and $2 \%$ lower in distant stage tumors $(13.1 \%$ vs $15.1 \%, \mathrm{P}<0.001)$. Multivariate analysis also indicated that widowed and divorced/separated patients had worse survival outcomes (Table 3).

\section{Effect of marital status on renal cancer CSS by patient sex}

We analyzed the influence of marital status on male and female patient survival separately. Log rank $\chi^{2}$ test results indicated that marital status affected renal cancer CSS $(\mathrm{P}<0.001)$ in both men and women (Figure 2). Both female and male widowed patients had the lowest 5-year CSS. However, multivariate analysis showed that compared with married male patients, widowed (hazard ratio [HR], 1.282; confidential interval [CI], 1.171-1.404; $\mathrm{P}<0.001$ ), single (hazard ratio [HR], 1.113; confidential interval $[\mathrm{CI}], 1.043-1.188 ; \mathrm{P}=0.001)$ and divorced/separated male patients (hazard ratio [HR], 1.204; confidential interval [CI], 1.118-1.296; $\mathrm{P}<0.001$ ) had poorer outcomes (Table 4). In female patients, only the divorced/separated group (hazard ratio [HR], 1.106; confidential interval [CI], 1.002-1.221; $\mathrm{P}=0.046$ ) had poorer outcomes (Table 4).

\section{Effect of marital status on renal cancer CSS by patient race}

Multivariate analysis results showed that black patients had worse survival outcomes than white patients, while other races had no survival differences compared with whites. Log rank $\chi 2$ test results showed that marital status affected renal cancer CSS $(\mathrm{P}<0.001)$ in both black and white patients (Figure 3 ). Similar to previous findings, white married patients had better survival outcomes than other white patient groups. However, black unmarried 
and married patients exhibited similar survival outcomes (Table 5).

\section{DISCUSSION}

The present study found that marital status is an independent prognostic factor for renal cancer, even after eliminating the influence of patient sex, age, race, tumor size, grade, laterality, and SEER stage. Widowed and separated/divorced patients had poorer survival rates compared with married patients. While a previous study suggested that male patients had better survival rates [15], female patients in our study had better 5-year CSS compared with male patients. As indicated by multivariate analysis, black patients had poorer outcomes than white patients. Patients with larger, more advanced stage, and higher-grade tumors had shorter survival times. Patients with bilateral tumors had the lowest 5-year CSS, possibly due to the presence of metastasis at diagnosis. Finally, patients with right-side renal tumors had slight better outcomes than those with left-side tumors. The reasons for this result need to be further investigated.

Our results also showed that male renal cancer patients benefited more from marriage than females. This trend was also observed in lung, colorectal, breast, pancreatic, prostate, liver/intrahepatic bile duct, nonHodgkin lymphoma, head/neck, ovarian, and esophageal cancer patients in another SEER-based study [16]. A potential reason for this disparity is that male patients might receive more social supports from their relatives and friends [16]. However, a systematic review and metaanalysis found no differences with respect to the effects of marriage on male and female patient outcomes [12]. Race

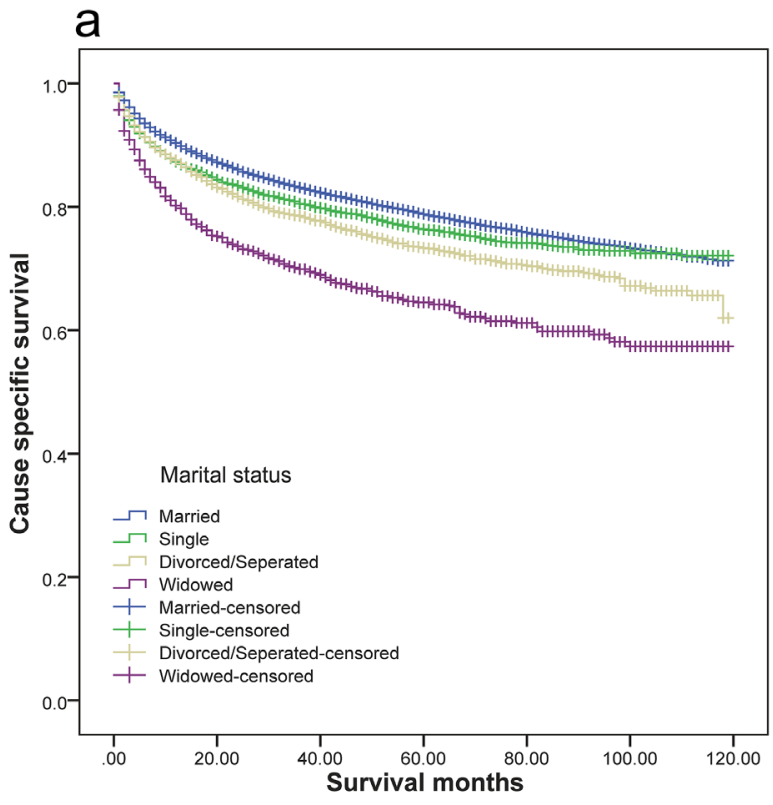

also influenced survival in patients with different marital statuses. Our results showed that marriage improved survival in white, but not black patients. Potential reasons for these findings must be clarified in future studies.

Although the association between marital status and cancer outcomes has been extensively investigated [8-10, $14,15]$, the intrinsic mechanisms behind this association remain poorly understood. On explanation might be that better financial resources and health care are available to married patients, enabling earlier disease detection and more favorable treatment options [14]. However, a recent assessment of patient insurance and neighborhood socioeconomic statuses indicated that marriage-associated survival benefits may not mediated by better access to material resources [17]. Another possible explanation is that married patients have better access to social and psychological support [14]. Cancer patients usually experience distress and anxiety from the time of diagnosis $[18,19]$. Without company and encouragement from a spouse, unmarried patients are more vulnerable to negative emotions. Evidence also suggests that psychological stress could promote tumor progression by disturbing normal immune and endocrine system functions $[12,14,20]$. Chronic psychological stress promotes cortisol secretion [21], which downregulates cortisol in white blood cells. This downregulation impairs cell responses to antiinflammatory signals and induces excessive cytokinemediated inflammatory processes [22], which are associated with cancer progression [23, 24]. Moreover, long term stress dysregulates immune function by altering the Type 1-Type 2 cytokine balance, inducing low-grade chronic inflammation, and inhibiting immune protective cell functions [25], all of which are associated with cancer metastasis [26-28].

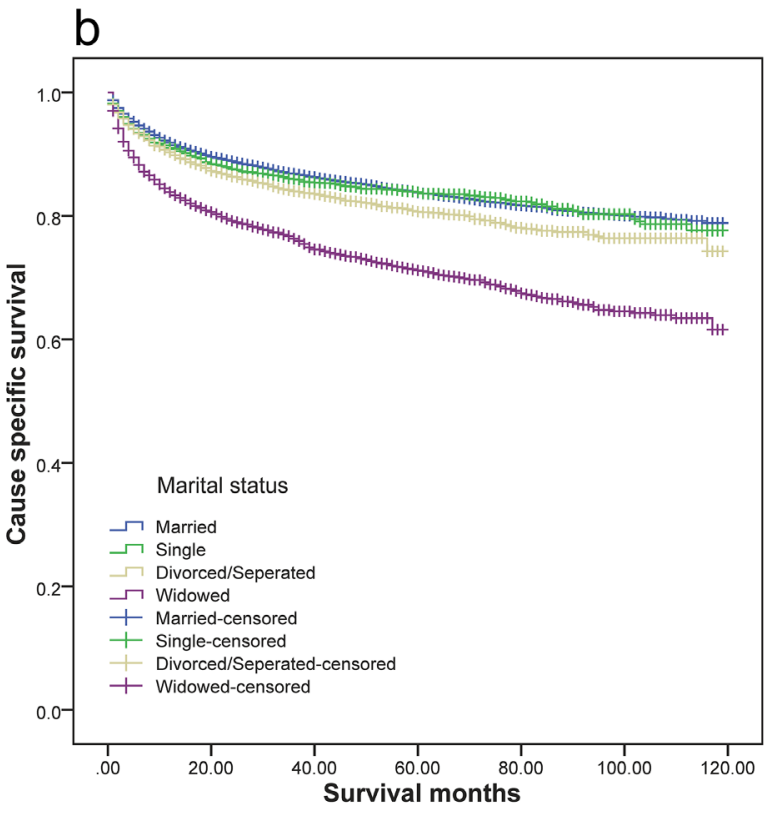

Figure 2: Survival curves of renal cancer patients according to marital status. (a) Male: $\chi^{2}=244.151, P<0.001$; (b) female; $\chi^{2}=366.889, \mathrm{P}<0.001$. 
Table 4: Univariate and multivariate analyses of the impact of marital status on renal cancer CSS based on patient sex

\begin{tabular}{|c|c|c|c|c|c|}
\hline \multirow{2}{*}{ Variable } & \multirow{2}{*}{ 5-year CSS } & \multicolumn{2}{|c|}{ Univariate analysis } & \multicolumn{2}{|c|}{ Multivariate analysis } \\
\hline & & Log rank $\chi^{2}$ test & $P$-value & HR $(95 \%$ CI $)$ & $P$-value \\
\hline \multicolumn{6}{|l|}{ Sex } \\
\hline \multicolumn{6}{|l|}{ Male } \\
\hline Marital status & & 244.151 & $<0.001$ & & \\
\hline Married & $78.7 \%$ & & & Reference & \\
\hline Widowed & $64.3 \%$ & & & $1.282(1.171-1.404)$ & $<0.001$ \\
\hline Single & $76.2 \%$ & & & $1.113(1.043-1.188)$ & 0.001 \\
\hline Divorced/Separated & $73.2 \%$ & & & $1.204(1.118-1.296)$ & $<0.001$ \\
\hline \multicolumn{6}{|l|}{ Female } \\
\hline Marital status & & 366.889 & $<0.001$ & & \\
\hline Married & $83.7 \%$ & & & Reference & \\
\hline Widowed & $71.0 \%$ & & & $1.065(0.983-1.154)$ & 0.124 \\
\hline Single & $83.8 \%$ & & & $0.917(0.828-1.016)$ & 0.098 \\
\hline Divorced/Separated & $80.6 \%$ & & & $1.106(1.002-1.221)$ & 0.046 \\
\hline
\end{tabular}

Additionally, diurnal cortisol rhythms were associated with cancer patient survival $[29,30]$. High quality psychological support from a spouse and perceived social support were associated increased natural killer cell activity [31]. Depression was also correlated with patient noncompliance with medical treatment recommendations [32].

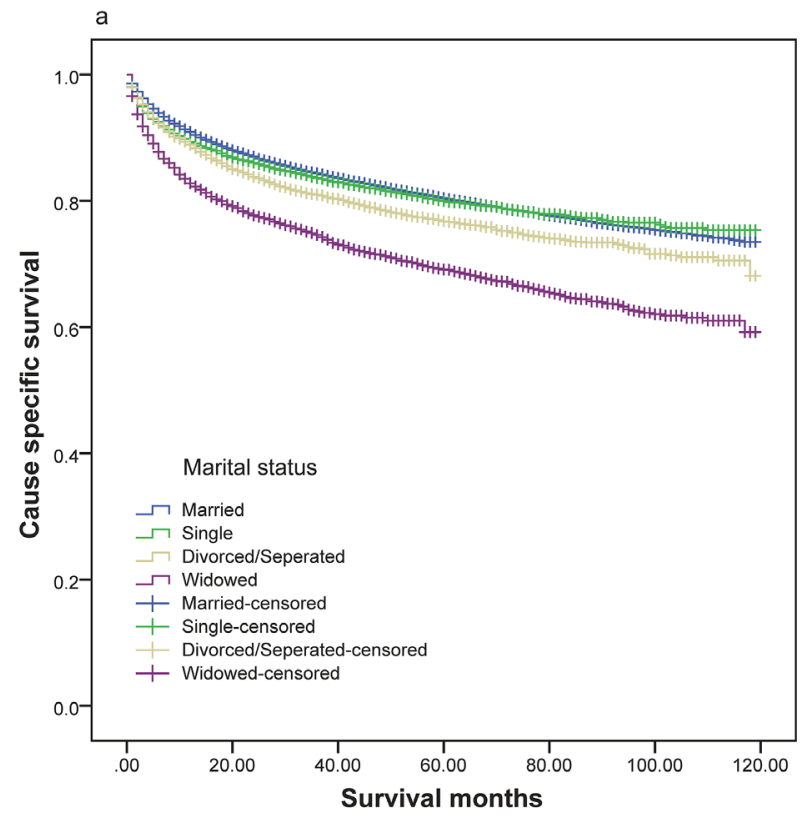

This study had certain limitations. First, the SEER database only documented patient marital status at diagnosis. Patient marital statuses might have changed over the course of treatment, which could have influenced survival outcomes. Additionally, marriage quality might also impact spousal support levels, and this information

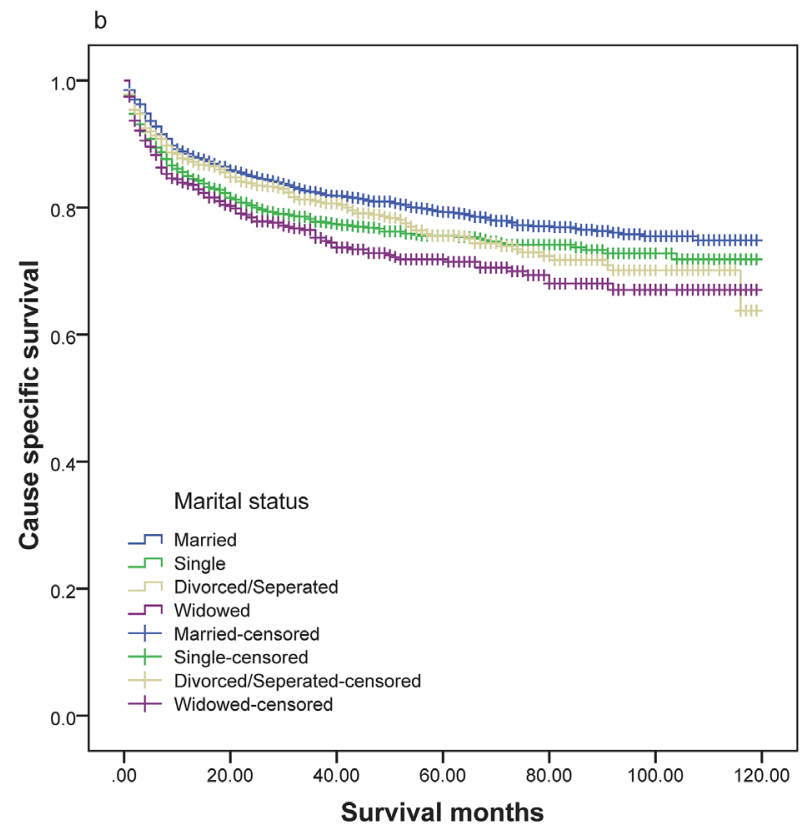

Figure 3: Survival curves of renal cancer patients according to marital status. (a) White: $\chi^{2}=394.370, \mathrm{P}<0.001$; (b) black; $\chi^{2}=21.205, \mathrm{P}<0.001$. 
Table 5: Univariate and multivariate analyses of the impacts of marital status on renal cancer CSS based on patient race

\begin{tabular}{|c|c|c|c|c|c|}
\hline \multirow{2}{*}{ Variable } & \multirow{2}{*}{ 5-year CSS } & \multicolumn{2}{|c|}{ Univariate analysis } & \multicolumn{2}{|c|}{ Multivariate analysis } \\
\hline & & Log $\operatorname{rank} \chi^{2}$ test & $P$-value & HR $(95 \%$ CI $)$ & $P$-value \\
\hline \multicolumn{6}{|l|}{ Race } \\
\hline \multicolumn{6}{|l|}{ White } \\
\hline Marital status & & 394.370 & $<0.001$ & & \\
\hline Married & $80.3 \%$ & & & Reference & \\
\hline Widowed & $68.9 \%$ & & & $\begin{array}{c}1.182(1.108- \\
1.261)\end{array}$ & $<0.001$ \\
\hline Single & $79.8 \%$ & & & $\begin{array}{c}1.013(0.951- \\
1.080)\end{array}$ & 0.679 \\
\hline Divorced/Separated & $76.6 \%$ & & & $\begin{array}{c}1.158(1.085- \\
1.235)\end{array}$ & $<0.001$ \\
\hline \multicolumn{6}{|l|}{ Black } \\
\hline Marital status & & 21.205 & $<0.001$ & & \\
\hline Married & $79.2 \%$ & & & Reference & \\
\hline Widowed & $71.7 \%$ & & & $\begin{array}{c}1.038(0.824- \\
1.280)\end{array}$ & 0.724 \\
\hline Single & $75.4 \%$ & & & $\begin{array}{c}1.123(0.966- \\
1.304)\end{array}$ & 0.130 \\
\hline Divorced/Separated & $75.4 \%$ & & & $\begin{array}{c}1.149(0.959- \\
1.378)\end{array}$ & 0.132 \\
\hline
\end{tabular}

was not included in the database. Second, the SEER database did not provide other important information, such as patient access to socioeconomic resources, which could influence the association between prognosis and marital status.

Despite these limitations, our study demonstrated a direct association between cancer patient marital status and prognosis based on a large and representative population. In summary, married patients had better survival rates than unmarried patients. We speculated that psychosocial and socioeconomic statuses might contribute to the better outcomes of married patients. This study highlights the importance of psychological intervention for cancer patients during treatment, especially for those who are unmarried.

\section{MATERIALS AND METHODS}

\section{Data sources}

All primary data were obtained from the SEER Program, including cancer incidence, stage, grade, therapy type(s), and population data, such as patient age, sex, race, and geographic region. The current dataset used for this study was based on Incidence-SEER 18 Regs Research
Data + Hurricane Katrina Impacted Louisiana Cases, Nov 2015 Sub (1973-2013 varying).

\section{Patient selection and data extraction}

We assessed renal cancer patients from the SEER database using SEER*Stat 8.3.2. Patients were selected according to the following criteria: (1) aged $\geq 18$ years at diagnosis; (2) diagnosed between 2004 and 2013; (3) histological types were limited to clear cell adenocarcinoma and renal cell carcinoma (code 8310, 8312); (4) marital status was limited to married (including common law), divorced, separated, widowed, or single (never married). Patients with unknown cause of death, unknown survival time (months), or incomplete date information were excluded. Gender, age, race, marital status, grade, tumor size, laterality, SEER stage, cause of death, survival time, and survival months were extracted from the SEER database for each patient. This study was approved by the ethics committee of the Fourth Affiliated Hospital of Harbin Medical University (Harbin, China).

\section{Statistical analysis}

Data were analyzed based on patient age, gender, race, marital status, tumor size, tumor grade, laterality, and 
SEER stage. Patients were divided into two age groups: $\leq 60$ and $>60$. Race classifications included white, black, American Indian/Alaska native, Asian or Pacific Islander, and unknown. Divorced or separated patients were classified together into the divorced/separated group.

Patient baseline characteristics were analyzed using the $\chi^{2}$ test. Patient survival rates were calculated using the Kaplan-Meier method. A multivariate Cox regression model was built to analyze survival outcome risk factors. The primary endpoint of this study was cancer causespecific death. Death resulting from renal cancer was assessed via events, and deaths due to other causes was considered censored events. All statistical analyses were performed using SPSS for Windows, v22 (SPSS Inc, Chicago, IL, USA). $\mathrm{P}<0.05$ (two-sided) was considered statistically significant.

\section{ACKNOWLEDGMENTS}

We acknowledge the efforts of the SEER Program in the creation of the SEER database. This manuscript's authors are responsible for all data interpretation and reporting herein.

\section{CONFLICTS OF INTEREST}

The authors declare that they have no conflicts of interest.

\section{GRANT SUPPORT}

This study was supported by grants from the National Nature Science Foundation (No: 81611130070 and No: 81602225) and Nature Science Foundation of Heilongjiang Province (No: QC201620).

\section{REFERENCES}

1. Capitanio U, Montorsi F. Renal cancer. Lancet. 2016; 387:894-906.

2. Siegel R, Ma J, Zou Z, Jemal A. Cancer statistics, 2014. CA Cancer J Clin. 2014; 64:9-29.

3. Theis RP, Dolwick Grieb SM, Burr D, Siddiqui T, Asal NR. Smoking, environmental tobacco smoke, and risk of renal cell cancer: a population-based case-control study. BMC Cancer. 2008; 8:387.

4. Deckers IA, van den Brandt PA, van Engeland M, van Schooten FJ, Godschalk RW, Keszei AP, Schouten LJ. Polymorphisms in genes of the renin-angiotensinaldosterone system and renal cell cancer risk: interplay with hypertension and intakes of sodium, potassium and fluid. Int J Cancer. 2015; 136:1104-1116.

5. Bergstrom A, Hsieh CC, Lindblad P, Lu CM, Cook NR, Wolk A. Obesity and renal cell cancer--a quantitative review. Br J Cancer. 2001; 85:984-990.
6. Gati A, Kouidhi S, Marrakchi R, El Gaaied A, Kourda N, Derouiche A, Chebil M, Caignard A, Perier A. Obesity and renal cancer: Role of adipokines in the tumor-immune system conflict. Oncoimmunology. 2014; 3:e27810.

7. Rohrmann S, Linseisen J, Overvad K, Lund Wurtz AM, Roswall N, Tjonneland A, Boutron-Ruault MC, Racine A, Bastide N, Palli D, Agnoli C, Panico S, Tumino R, et al. Meat and fish consumption and the risk of renal cell carcinoma in the European prospective investigation into cancer and nutrition. Int J Cancer. 2015; 136:E423-431.

8. He XK, Lin ZH, Qian Y, Xia D, Jin P, Sun LM. Marital status and survival in patients with primary liver cancer. Oncotarget. 2016. https://doi.org/10.18632/ oncotarget.11066. [Epub ahead of print].

9. Li M, Dai CY, Wang YN, Chen T, Wang L, Yang P, Xie D, Mao R, Chen C. Marital status is an independent prognostic factor for tracheal cancer patients: an analysis of the SEER database. Oncotarget. 2016; 7:77152-77162. https://doi.org/ 10.18632/oncotarget.12809.

10. Shi RL, Chen Q, Yang Z, Pan G, Zhang Z, Wang W, Liu S, Zhang D, Jiang D, Liu W. Marital status independently predicts gastric cancer survival after surgical resection--an analysis of the SEER database. Oncotarget. 2016; 7:1322813235. https://doi.org/10.18632/oncotarget.7107.

11. Seeman TE. Health promoting effects of friends and family on health outcomes in older adults. Am J Health Promot. 2000; $14: 362-370$.

12. Manzoli L, Villari P, M Pirone G, Boccia A. Marital status and mortality in the elderly: a systematic review and metaanalysis. Soc Sci Med. 2007; 64:77-94.

13. Bernstein AB, Cohen RA, Brett KM, Bush MA. Marital status is associated with health insurance coverage for working-age women at all income levels, 2007. NCHS Data Brief. 2008:1-8.

14. Rendall MS, Weden MM, Favreault MM, Waldron H. The protective effect of marriage for survival: a review and update. Demography. 2011; 48:481-506.

15. Qiu M, Yang D, Xu R. Impact of marital status on survival of gastric adenocarcinoma patients: results from the Surveillance Epidemiology and End Results (SEER) Database. Sci Rep. 2016; 6:21098.

16. Aizer AA, Chen MH, McCarthy EP, Mendu ML, Koo S, Wilhite TJ, Graham PL, Choueiri TK, Hoffman KE, Martin $\mathrm{NE}, \mathrm{Hu}$ JC, Nguyen PL. Marital status and survival in patients with cancer. J Clin Oncol. 2013; 31:3869-3876.

17. Gomez SL, Hurley S, Canchola AJ, Keegan TH, Cheng I, Murphy JD, Clarke CA, Glaser SL, Martinez ME. Effects of marital status and economic resources on survival after cancer: a population-based study. Cancer. 2016; 122:1618-1625.

18. Bodurka-Bevers D, Basen-Engquist K, Carmack CL, Fitzgerald MA, Wolf JK, de Moor C, Gershenson DM. Depression, anxiety, and quality of life in patients with epithelial ovarian cancer. Gynecol Oncol. 2000; 78:302-308. 
19. Tsunoda A, Nakao K, Hiratsuka K, Yasuda N, Shibusawa M, Kusano M. Anxiety, depression and quality of life in colorectal cancer patients. Int J Clin Oncol. 2005; 10:411-417.

20. Spiegel D, Sephton SE, Terr AI, Stites DP. Effects of psychosocial treatment in prolonging cancer survival may be mediated by neuroimmune pathways. Ann N Y Acad Sci. 1998; 840:674-683.

21. McEwen BS. Physiology and neurobiology of stress and adaptation: central role of the brain. Physiol Rev. 2007; 87:873-904.

22. Miller GE, Cohen S, Ritchey AK. Chronic psychological stress and the regulation of pro-inflammatory cytokines: a glucocorticoid-resistance model. Health Psychol. 2002; 21:531-541.

23. Qu JL, Qu XJ, Li Z, Zhang JD, Liu J, Teng YE, Jin B, Zhao MF, Yu P, Shi J, Fu LY, Wang ZN, Liu YP. Prognostic model based on systemic inflammatory response and clinicopathological factors to predict outcome of patients with node-negative gastric cancer. PLoS One. 2015; 10:e0128540.

24. Urabe M, Yamashita H, Seto Y. Pretreatment neutrophil to lymphocyte ratio independently predicts disease-specific survival in patients with resectable gastroesophageal junction and gastric cancer. Ann Surg. 2016; 263:292-297.

25. Dhabhar FS. Effects of stress on immune function: the good, the bad, and the beautiful. Immunol Res. 2014; 58:193-210.
26. Wculek SK, Malanchi I. Neutrophils support lung colonization of metastasis-initiating breast cancer cells. Nature. 2015; 528:413-417.

27. Williams KA, Labidi-Galy SI, Terry KL, Vitonis AF, Welch WR, Goodman A, Cramer DW. Prognostic significance and predictors of the neutrophil-to-lymphocyte ratio in ovarian cancer. Gynecol Oncol. 2014; 132:542-550.

28. Xu AM, Huang L, Zhu L, Wei ZJ. Significance of peripheral neutrophil-lymphocyte ratio among gastric cancer patients and construction of a treatment-predictive model: a study based on 1131 cases. Am J Cancer Res. 2014; 4:189-195.

29. Sephton SE, Lush E, Dedert EA, Floyd AR, Rebholz WN, Dhabhar FS, Spiegel D, Salmon P. Diurnal cortisol rhythm as a predictor of lung cancer survival. Brain Behav Immun. 2013; 30:S163-170.

30. Sephton SE, Sapolsky RM, Kraemer HC, Spiegel D. Diurnal cortisol rhythm as a predictor of breast cancer survival. J Natl Cancer Inst. 2000; 92:994-1000.

31. Levy SM, Herberman RB, Whiteside T, Sanzo K, Lee J, Kirkwood J. Perceived social support and tumor estrogen/ progesterone receptor status as predictors of natural killer cell activity in breast cancer patients. Psychosom Med. 1990; 52:73-85.

32. DiMatteo MR, Lepper HS, Croghan TW. Depression is a risk factor for noncompliance with medical treatment: metaanalysis of the effects of anxiety and depression on patient adherence. Arch Intern Med. 2000; 160:2101-2107. 